\title{
Effects of Pancreas Transplantation on Insulin Secretion in the Rat During Ingestion of Varying Glucose Loads
}

\author{
J. H. Strubbe \\ Department of Zoology, State University of Groningen, Haren, The Netherlands
}

Summary. Following alloxan induced diabetes in rats, transplantation of neonatal pancreases under the kidney capsule was successfully carried out. The insulin response to oral ingestion of 150 and $750 \mathrm{mg}$ of glucose was studied. The responses in controls and in rats 40 days after transplantation demonstrated a load-dependent increment of plasma insulin responses which was not related to the similar glucose responses. In control rats a part of the insulin response had occurred at $1 \mathrm{~min}$, i. e. $2 \mathrm{~min}$ before the rise in blood glucose. After transplantation in the absence of this nervously triggered response, blood glucose rose faster than in control rats from 3 to $5 \mathrm{~min}$ after start of ingestion $(p<0.01)$. In non-transplanted rats regenerating a part of their original pancreas within one week, glucose intolerance was seen 10 min after glucose ingestion, probably due to the lack of adequate secondary phase release. This study shows that maintenance of a normal glucose tolerance curve to glucose ingestion depends on at least two factors. First, an anticipatory nervously triggered insulin secretion. Second, a load dependent humoral potentiation of glucose stimulated insulin release.

Key words: Pancreas transplantation, insulin secretion, food intake, blood glucose.

Previous studies in the rat have shown that the pattern and magnitude of glucose-induced insulin secretion depends on the route of glucose administration [1]. Intravenous infusion of glucose elicits a rapid rise of plasma insulin which is followed by a slow secondary rise. The magnitude of responses is closely related to the infused load and the degree and rate of glucose elevation [1-3].

Likewise oral administration of glucose elicits a load dependent increase of plasma insulin [1, 4]; but this response develops more gradually and the relationship with blood glucose appears to be different
[1]. After oral glucose ingestion in rats, a part of this response occurs at $1 \mathrm{~min}$, i. e. $2 \mathrm{~min}$ before the first rise of blood glucose. There is available evidence showing that this preabsorptive insulin response is under nervous control [1,5-10]. After ingestion of different loads of glucose, maximum blood glucose levels do not differ very much and do not correlate with the ingested loads. However, maximum plasma insulin levels and the insulinogenic index increases with higher glucose loads $[1,4]$. These results suggest that the plasma insulin response to glucose ingestion is a result of both an anticipatory, nervously triggered insulin secretion and load-dependent potentiation of secretory stimulation by rising blood glucose.

In a recent study it has been shown that pancreas transplantation in diabetic rats results in denervated, well vascularized insulin secretory tissue which could only be stimulated by humoral factors. After ingestion of food the preabsorptive insulin response was absent [10]. This finding has also been confirmed by others $[11,12]$.

The aim of the present study was to investigate further the insulin response to different oral glucose loads in conscious rats who had received neonatal pancreatic transplants, with particular reference to the role of the autonomic nervous system.

\section{Materials and Methods}

\footnotetext{
Animals

Male rats of the highly inbred AO strain weighing 305-330 g were kept in perspex cages at a room temperature of approximately $20^{\circ} \mathrm{C}$. The light phase was from 0600 to $1800 \mathrm{~h}$. Food pellets and water were supplied ad libitum. Experimental diabetes was produced by an IV injection of alloxan $45 \mathrm{mg} / \mathrm{kg}$ body weight (British Drug Houses, Poole, UK) after a fasting period of $24 \mathrm{~h}$. In some of the rats treated with alloxan, glycosuria disappeared 7-9 days after alloxan injection. These rats had probably less B cell damage and were able to regenerate a part of their insulin producing tissue. Histological examination showed a decrease of about $30 \%$ in the number of stained B cells in this group. This regenerated group was tested for comparison with the transplanted group and a third group of normal controls. Six rats were used in each group.
} 


\section{Renal Subcapsular Transplantation}

After 3-4 weeks the diabetic rats received eight neonate pancreases each, placed under the kidney capsules as described by Brown et al. [13]. The group who failed to show persistent glycosuria and the normal control rats $(n=6)$ were sham operated. All rats were administered $6 \mathrm{U}$ of the long acting protamine zinc insulin (Organon, Oss, The Netherlands) subcutaneously for three days according to Brown et al. [13]. This insulin treatment was necessary for a good functioning of the transplanted pancreases.

\section{Implantation of Cannulae}

Two weeks after transplantation or sham operation the rats were provided with a permanent heart catheter as described by Steffens [14]. This catheter allows blood sampling in the freely moving rat. The rats were handled for a few days to become accustomed to the sampling procedure.

\section{Experimental Design and Conditions}

Food was removed from the cage $2 \mathrm{~h}$ before the start of the experiment. The six rats used for each test received a low $(150 \mathrm{mg})$ and a high glucose load $(750 \mathrm{mg})$. These loads were given by allowing the animals to lick volumes of $1.5 \mathrm{ml}$ glucose solution $(10 \%, \mathrm{w} / \mathrm{v})$ for

Table 1. Absolute plasma insulin and blood glucose levels at the start of glucose ingestion

\begin{tabular}{lcccl}
\hline Rat groups & $\begin{array}{l}\text { Load } \\
(\mathrm{mg})\end{array}$ & Line & $\begin{array}{l}\text { Plasma } \\
\text { insulin } \\
(\mathrm{mU} / \mathrm{l})\end{array}$ & $\begin{array}{l}\text { Blood glucose } \\
(\mathrm{mmol} / \mathrm{l})\end{array}$ \\
\hline Control & 150 & $\mathrm{a}$ & $27 \pm 3$ & $5.94 \pm 0.11$ \\
& 750 & $\mathrm{~b}$ & $24 \pm 3$ & $5.67 \pm 0.17$ \\
Transplanted & 150 & $\mathrm{c}$ & $38 \pm 3$ & $6.11 \pm 0.11$ \\
$\quad$ 20 days & 750 & $\mathrm{~d}$ & $43 \pm 3$ & $6.20 \pm 0.11$ \\
Transplanted & 150 & $\mathrm{e}$ & $40 \pm 2$ & $5.83 \pm 0.17$ \\
$\quad$ 40 days & 750 & $\mathrm{f}$ & $41 \pm 2$ & $5.94 \pm 0.06$ \\
Regenerated & 150 & $\mathrm{~g}$ & $32 \pm 4$ & $6.11 \pm 0.11$ \\
$\quad$ 40 days & 750 & $\mathrm{~h}$ & $34 \pm 3$ & $6.06 \pm 0.06$ \\
\hline
\end{tabular}

Results expressed as mean \pm SEM

Plasma insulin: a versus $\mathrm{c}, \mathrm{d}, \mathrm{e}, \mathrm{f}: p<0.05$ the $150 \mathrm{mg}$ and $50 \%(\mathrm{w} / \mathrm{v})$ for the $750 \mathrm{mg}$ load. The choice of a moderate $(150 \mathrm{mg})$ and a high load $(750 \mathrm{mg})$ was adopted from a previous report [1]. The average time required for ingestion of these amounts was $1 \mathrm{~min}$. Each of the loads of glucose was tested on separate days in randomized order with an interval of one day between each test. Transplanted rats were tested at days 19 and 21 after transplantation and on days 39 and 41 . For comparison the control and regenerated groups were tested at days 39 and 41 after operation.

The blood samples were taken $10 \mathrm{~min}$ and immediately before the oral test. The response was studied by sampling at $1,2,3,5,10$, $15,20,25,30,40,50$ and $60 \mathrm{~min}$ after initiation of licking. Blood samples of $0.2 \mathrm{ml}$ were taken and $5 \mu \mathrm{l}$ of heparin $(500 \mathrm{U} / \mathrm{ml})$ were added to each sample. Blood was replenished by transfusion of citrated blood through the sample catheter during the experiments. Tests were always performed between 0900 and $1200 \mathrm{~h}$.

\section{Insulin and Glucose Determinations}

The presence of glucose in the urine was tested for by using Lilly Testape (Bipharma, Amsterdam, The Netherlands). Blood samples were immediately chilled and centrifuged at $4^{\circ} \mathrm{C}$. The plasma was stored at $-20^{\circ} \mathrm{C}$ until analysis. The blood glucose concentration was measured from whole blood by a ferricyanide method with a Technicon autoanalyzer. Plasma insulin was measured by a radioimmunoassay kit (Novo, Denmark) using a rat insulin standard,

${ }^{125} \mathrm{I}$-labelled pork insulin and antipork insulin guinea pig serum M8309. Duplicate assays were performed on $25 \mu 1$ samples. Plasma $(25 \mu \mathrm{l})$ from alloxan-diabetic rats was added to each of the standards. The separation of bound and free ${ }^{125} \mathrm{I}$-labelled insulin was performed by means of a polyethylene glycol solution $(23.75 \%$, $\mathrm{w} / \mathrm{w})$ in water. The coefficient of variation of the immunoassay was $<8 \%$.

\section{Statistical Analysis and Calculation}

Differences were tested for statistical significance with Student's t-test (two tailed), $p<0.05$ was considered significant.

\section{Results}

Basal blood glucose levels were not different in the four groups (Table 1). The basal plasma insulin levels of the transplanted group after 20 and 40 days were

Table 2. Blood glucose increments (mmol/1) from the start of ingestion of 150 and $750 \mathrm{mg}$ of glucose onwards

\begin{tabular}{|c|c|c|c|c|c|c|c|c|}
\hline \multirow{3}{*}{$\begin{array}{l}\text { Time } \\
\text { (min) }\end{array}$} & \multirow{2}{*}{\multicolumn{2}{|c|}{$\frac{\text { Control rats }}{\text { Glucose load at } 40 \text { days }}$}} & \multicolumn{4}{|c|}{ Transplanted rats } & \multirow{2}{*}{\multicolumn{2}{|c|}{$\frac{\text { Regenerated rats }}{\text { Glucose load at } 40 \text { days }}$}} \\
\hline & & & \multicolumn{2}{|c|}{ Glucose load at 20 days } & \multicolumn{2}{|c|}{ Glucose load at 40 days } & & \\
\hline & $150 \mathrm{mg}$ & $750 \mathrm{mg}$ & $150 \mathrm{mg}$ & $750 \mathrm{mg}$ & $150 \mathrm{mg}$ & $750 \mathrm{mg}$ & $150 \mathrm{mg}$ & $750 \mathrm{mg}$ \\
\hline 1 & $0.01 \pm 0.06$ & $-0.03 \pm 0.07$ & $0.04 \pm 0.06$ & $-0.08 \pm 0.01$ & $0.01 \pm 0.06$ & $-0.02 \pm 0.06$ & $-0.01 \pm 0.10$ & $0.02 \pm 0.06$ \\
\hline 2 & $0.17 \pm 0.11$ & $0.13 \pm 0.09$ & $0.12 \pm 0.13$ & $0.09 \pm 0.01$ & $0.18 \pm 0.06$ & $0.11 \pm 0.05$ & $0.11 \pm 0.14$ & $0.19 \pm 0.11$ \\
\hline 3 & $0.47 \pm 0.13$ & $0.42 \pm 0.06$ & $0.36 \pm 0.06$ & $0.89 \pm 0.01$ & $0.34 \pm 0.04$ & $0.15 \pm 0.06$ & $0.87 \pm 0.25$ & $0.17 \pm 0.04$ \\
\hline 5 & $0.98 \pm 0.24$ & $0.79 \pm 0.15$ & $1.32 \pm 0.17$ & $2.19 \pm 0.06$ & $1.16 \pm 0.04$ & $1.11 \pm 0.20$ & $1.38 \pm 0.22$ & $0.64 \pm 0.10$ \\
\hline 10 & $1.95 \pm 0.32$ & $1.88 \pm 0.18$ & $1.90 \pm 0.13$ & $3.68 \pm 0.14$ & $1.83 \pm 0.12$ & $2.32 \pm 0.29$ & $1.94 \pm 0.18$ & $1.97 \pm 0.09$ \\
\hline 15 & $1.84 \pm 0.18$ & $2.10 \pm 0.33$ & $1.74 \pm 0.21$ & $4.44 \pm 0.23$ & $1.56 \pm 0.12$ & $2.30 \pm 0.30$ & $2.87 \pm 0.22$ & $4.20 \pm 0.10$ \\
\hline 20 & $1.28 \pm 0.11$ & $2.05 \pm 0.31$ & $1.52 \pm 0.23$ & $4.19 \pm 0.43$ & $0.92 \pm 0.16$ & $2.38 \pm 0.32$ & $2.96 \pm 0.11$ & $3.98 \pm 0.36$ \\
\hline 25 & $0.82 \pm 0.13$ & $1.80 \pm 0.21$ & $0.90 \pm 0.20$ & $4.2 \pm 0.54$ & $0.73 \pm 0.16$ & $2.10 \pm 0.19$ & $2.98 \pm 0.05$ & $4.96 \pm 0.19$ \\
\hline 30 & $0.54 \pm 0.11$ & $1.66 \pm 0.17$ & $0.76 \pm 0.23$ & $4.26 \pm 0.55$ & $0.44 \pm 0.07$ & $1.87 \pm 0.23$ & $3.05 \pm 0.34$ & $5.24 \pm 0.45$ \\
\hline 40 & $0.32 \pm 0.08$ & $1.31 \pm 0.20$ & $0.44 \pm 0.19$ & $4.14 \pm 0.46$ & $0.40 \pm 0.07$ & $1.70 \pm 0.31$ & $1.41 \pm 0.17$ & $5.81 \pm 0.26$ \\
\hline 50 & $0.23 \pm 0.08$ & $1.72 \pm 0.26$ & $0.58 \pm 0.15$ & $2.26 \pm 0.34$ & $0.50 \pm 0.08$ & $1.69 \pm 0.16$ & $1.23 \pm 0.18$ & $3.19 \pm 0.31$ \\
\hline 60 & $0.24 \pm 0.14$ & $1.90 \pm 0.29$ & $0.49 \pm 0.15$ & $1.28 \pm 0.14$ & $0.33 \pm 0.12$ & $1.37 \pm 0.20$ & $0.56 \pm 0.12$ & $2.01 \pm 0.29$ \\
\hline
\end{tabular}

Results expressed as mean \pm SEM 
Table 3. Plasma insulin increments $(\mathrm{mU} / 1)$ from the start of ingestion of 150 and $750 \mathrm{mg}$ of glucose onwards

\begin{tabular}{|c|c|c|c|c|c|c|c|c|}
\hline \multirow{3}{*}{$\begin{array}{l}\text { Time } \\
(\min )\end{array}$} & \multirow{2}{*}{\multicolumn{2}{|c|}{$\frac{\text { Control rats }}{\text { Glucose load at } 40 \text { days }}$}} & \multicolumn{4}{|c|}{ Transplanted rats } & \multirow{2}{*}{\multicolumn{2}{|c|}{$\frac{\text { Regenerated rat }}{\text { Glucose load at } 40 \text { days }}$}} \\
\hline & & & \multicolumn{2}{|c|}{ Glucose load at 20 days } & \multicolumn{2}{|c|}{ Glucose load at 40 days } & & \\
\hline & $150 \mathrm{mg}$ & $750 \mathrm{mg}$ & $150 \mathrm{mg}$ & $750 \mathrm{mg}$ & $150 \mathrm{mg}$ & $750 \mathrm{mg}$ & $150 \mathrm{mg}$ & $750 \mathrm{mg}$ \\
\hline 1 & $19.0 \pm 1.5$ & $16.0 \pm 1.6$ & $-4.0 \pm 2.6$ & $0.2 \pm 0.7$ & $-0.3 \pm 2.1$ & $0.7 \pm 0.8$ & $22.2 \pm 3.5$ & $26.2 \pm 5.0$ \\
\hline 2 & $21.2 \pm 2.1$ & $9.7 \pm 1.7$ & $2.2 \pm 3.6$ & $0.8 \pm 0.9$ & $15.5 \pm 2.2$ & $1.5 \pm 5.3$ & $11.7 \pm 0.7$ & $25.8 \pm 7.4$ \\
\hline 3 & $17.2 \pm 5.5$ & $22.2 \pm 2.7$ & $3.5 \pm 5.8$ & $2.7 \pm 1.9$ & $20.3 \pm 4.9$ & $16.7 \pm 5.5$ & $15.7 \pm 2.8$ & $13.7 \pm 7.4$ \\
\hline 5 & $25.3 \pm 4.7$ & $32.0 \pm 2.4$ & $46.3 \pm 10.8$ & $39.2 \pm 6.3$ & $61.8 \pm 7.0$ & $52.8 \pm 9.3$ & $16.0 \pm 0.9$ & $19.3 \pm 4.6$ \\
\hline 10 & $49.3 \pm 8.4$ & $91.3 \pm 14.4$ & $36.0 \pm 6.3$ & $61.2 \pm 6.2$ & $49.3 \pm 3.8$ & $91.8 \pm 12.7$ & $22.0 \pm 3.8$ & $33.0 \pm 7.1$ \\
\hline 15 & $31.8 \pm 2.6$ & $132.0 \pm 20.2$ & $23.2 \pm 4.5$ & $112.2 \pm 15.4$ & $27.2 \pm 5.9$ & $111.3 \pm 16.3$ & $18.5 \pm 1.5$ & $42.2 \pm 15.2$ \\
\hline 20 & $11.5 \pm 1.3$ & $88.2 \pm 18.1$ & $5.3 \pm 2.3$ & $145.2 \pm 6.9$ & $7.2 \pm 4.3$ & $108.0 \pm 16.2$ & $16.5 \pm 4.1$ & $46.5 \pm 12.5$ \\
\hline 25 & $4.3 \pm 1.4$ & $94.2 \pm 22.1$ & $4.7 \pm 3.2$ & $135.7 \pm 13.2$ & $5.2 \pm 3.6$ & $95.3 \pm 14.8$ & $2.3 \pm 3.5$ & $37.0 \pm 3.3$ \\
\hline 30 & $5.7 \pm 3.6$ & $58.2 \pm 8.6$ & $-2.2 \pm 3.1$ & $94.5 \pm 20.0$ & $0.3 \pm 4.1$ & $78.8 \pm 9.1$ & $5.8 \pm 2.7$ & $34.0 \pm 3.6$ \\
\hline 40 & $-1.7 \pm 2.3$ & $30.0 \pm 3.2$ & $0.7 \pm 3.4$ & $101.3 \pm 11.2$ & $3.8 \pm 2.8$ & $62.2 \pm 7.3$ & $8.2 \pm 5.0$ & $29.5 \pm 5.2$ \\
\hline 50 & $-3.0 \pm 2.0$ & $41.3 \pm 7.8$ & $4.0 \pm 4.2$ & $17.5 \pm 5.8$ & $6.5 \pm 3.4$ & $72.3 \pm 7.6$ & $6.3 \pm 2.4$ & $23.2 \pm 3.3$ \\
\hline 60 & $-2.3 \pm 3.2$ & $34.7 \pm 7.5$ & $1.0 \pm 4.6$ & $-11.0 \pm 2.8$ & $3.3 \pm 3.8$ & $36.3 \pm 9.2$ & $8.3 \pm 2.4$ & $25.5 \pm 5.2$ \\
\hline
\end{tabular}

Results expressed as mean \pm SEM

slightly higher than those of the control and regenerated rats $(p<0.05)$.

After ingestion of $150 \mathrm{mg}$ and $750 \mathrm{mg}$ of glucose, the first significant rise of blood glucose levels occurred at $3 \mathrm{~min}$ after the start of glucose ingestion (Table 2). At both loads, in control and regenerated rats, plasma insulin increased by $1 \mathrm{~min}$ after the start of glucose ingestion, i.e. $2 \mathrm{~min}$ before the first noticeable rise of blood glucose. In contrast, this glucose independent early insulin response was absent in the transplanted rats after both glucose loads (Table 3). In the transplanted rats after both loads the blood glucose rise from 3 to $5 \mathrm{~min}$ was higher than those of the control and regenerated groups (Table 4). The control and regenerated groups, however, showed a significant preabsorptive insulin response.

At $10 \mathrm{~min}$, most of the blood glucose levels in the control, transplanted and regenerated groups were almost the same for the 150 and $750 \mathrm{mg}$ loads except for a much higher level after 20 days of transplantation with the $750 \mathrm{mg}$ load (Table 2). Therefore it was evident that in the first $10 \mathrm{~min}$ the size of the load hardly influenced the magnitude of the blood glucose rise. Increasing the size of the load, however, delayed the decline of blood glucose level to basal values.

Comparing plasma insulin responses of the transplanted rats, it can be seen that plasma insulin increased more in the first 10 min 40 days after transplantation compared with 20 days after (Table 3 ). The decline of plasma insulin was delayed at higher loads of glucose. This delay was more evident after pancreatic transplantation.

In all groups ingestion of glucose induced a marked load-dependent increase in the insulin response which was evident at the maximum levels as well as after $10 \mathrm{~min}$ (Table 3 ).
Table 4. Blood glucose increments from 3 to 5 min after the start of glucose ingestion

\begin{tabular}{llll}
\hline Rat group & $\begin{array}{l}\text { Load } \\
(\mathrm{mg})\end{array}$ & Line & $\begin{array}{l}\Delta \text { Blood glucose } \\
(\mathrm{mmol} / \mathrm{l})\end{array}$ \\
\hline Control & 150 & $\mathrm{a}$ & $0.52 \pm 0.11$ \\
Transplanted 20 days & 150 & $\mathrm{c}$ & $0.96 \pm 0.18$ \\
& 750 & $\mathrm{~d}$ & $1.32 \pm 0.06$ \\
Transplanted 40 days & 150 & $\mathrm{e}$ & $0.82 \pm 0.02$ \\
Regenerated 40 days & 750 & $\mathrm{f}$ & $1.00 \pm 0.16$ \\
& 750 & $\mathrm{~g}$ & $0.51 \pm 0.18$ \\
& 750 & $\mathrm{~h}$ & $0.48 \pm 0.08$ \\
\hline
\end{tabular}

Results expressed as mean $\pm \mathrm{SEM}$

b versus $\mathrm{d} p<0.001 ; \mathrm{b}$ versus $\mathrm{f} p<0.01$

\section{Discussion}

In a recent study it has been shown that after food intake, the rapid glucose-independent preabsorptive rise of insulin is absent in rats provided with functional neonatal pancreas transplants [10]. The present results confirm these findings. The transplants secreted insulin within one minute after intravenous glucose stimulation [10]. As presented elsewhere, histology and electron microscopy of these transplanted pancreases showed vascularized clusters of well granulated B cells. After transplantation there were $1 \%-2 \%$ of stained B cells left from the original pancreas [10]. This has been confirmed by others [15]. Since blood glucose and plasma insulin levels of sham operated diabetic rats varied after meal ingestion from 27 to $31 \mathrm{mmol} / 1$ and 0 to $3 \mathrm{mU} / 1$ respectively, it is unlikely that the original pancreas secreted significant amounts of insulin [10]. 
These findings together with the results of the present study strongly suggest that the triggering of the preabsorptive insulin response after food intake is mainly under nervous control. Since vagotomy $[8,9$, 11] or pharmacological blockade of muscarinic receptors by atropine [5,7] can abolish the preabsorptive insulin response, it is suggested that the vagus nerve plays an important role in its causation [1,5-10].

Comparing the results of control, regenerated and transplanted rats, it is shown that the nervously triggered initial insulin release in the first 2 min determined the steepness of the glucose increments over the first $10 \mathrm{~min}$ and in particular from the third to the fifth minute. The small deviations in glucose tolerance in the transplanted group after 40 days may therefore be attributed to the lack of innervation, though effects due to different drainage and the number and sensitivity of B cells cannot be excluded [10]. Initial insulin release may play a role in depressing the rising glucose levels but thereafter secondary phase release is important as shown by the glucose intolerance of the regenerated pancreas group.

In control rats and in the group 40 days after transplantation, the maximum glucose levels after $750 \mathrm{mg}$ were almost the same as those levels of the much lower glucose load of $150 \mathrm{mg}$. In both the control and transplanted rats, however, insulin increased with increasing loads. These findings indicate that the loaddependent increase of insulin response to glucose is determined by factors other than blood glucose increment alone. These data are in agreement with those of a previous study [1].

Since the transplanted group probably possessed denervated $\mathrm{B}$ cells the potentiating factors will presumably be of a humoral nature. Secretin, cholecystokinin, GIP and other intestinal peptides are likely candidates for this role $[16,17]$. Rapid load-dependent release of these humoral factors would furnish an attractive model to explain anticipatory load-dependent potentiation of the insulinogenic effect of alimentary hyperglycaemia.

Thus the maintenance of a normal glucose tolerance curve to glucose ingestion depends on at least two factors. First, an anticipatory nervously triggered insulin secretion. Second, a load-dependent humoral potentiation of glucose stimulated insulin release.

Acknowledgements. I thank Drs. N.J.Spiteri, P.van Wachem and R. Remie for their helpful comments. This investigation was supported (in part) by the Foundation for Medical Research (FUNGO) which is subsidized by the Netherlands Organization for the Advancement of Pure Research (ZWO).

\section{References}

1. Strubbe JH, Bouman PR (1978) Plasma insulin patterns in the unanesthetized rat during intracardial infusion and spontane- ous ingestion of graded loads of glucose. Metabolism 27: 341-351

2. Cerasi E, Luft R, Efendic S (1972) Decreased sensitivity of the pancreatic beta cell to glucose in prediabetic and diabetic subjects. A glucose dose-response study. Diabetes 21:224-234

3. Efendic S, Cerasi E, Luft R (1974) Quantitative study on the potentiating effect of arginine on glucose-induced insulin response in healthy, prediabetic and diabetic subjects. Diabetes 23: $161-171$

4. Cerasi E, Efendic S, Luft R (1973) Dose-response relation between plasma-insulin and blood glucose levels during oral glucose loads in prediabetic and diabetic subjects. Lancet 1: 794-797

5. Strubbe JH, Steffens AB (1975) Rapid insulin release after ingestion of a meal in the unanesthetized rat. Am J Physiol 229: 1019-1022

6. De Jong A, Strubbe JH, Steffens AB (1977) Hypothalamic influence on insulin and glucagon release in the rat. Am $\mathbf{J}$ Physiol $223: 380-388$

7. Fischer U, Hommel H, Freyse EJ, Fiedler H (1975) Der Mechanismus der Insulinsekretion nach oraler Glukoseverabfolgung. IV. Verhinderung der reflektorischen Frühphase des Plasmainsulin-Anstieges durch Atropin. Endokrinologie 65:91-102

8. Fischer U, Hommel H, Ziegler M, Nowak W, Hahn von Dorsche H (1976) The mechanism of insulin secretion after oral glucose administration. VIII. Pancreatic juice insulin excretion after glucose loading and meal ingestion in normal and vagotomized dogs. Endokrinologie 68:327-337

9. Fischer U, Hommel H, Nowak W, Hahn von Dorsche H, Sill U, Lippert H (1976) Der Einfluß der Vagotomie auf die Glukosetoleranz sowie die Reaktionen von Plasmainsulin und exokriner Pankreasfunktion nach Glukosebelastung oder Nahrungsaufnahme bei Hunden. Acta Biol Med Germ 35: 1279-1291

10. Strubbe JH, van Wachem $P$ (1981) Insulin secretion by the transplanted neonatal pancreas during food intake in fasted and fed rats. Diabetologia 20:228-236

11. Louis-Sylvestre J (1978) Feeding and metabolic patterns in rats with truncular vagotomy or with transplanted B cells. Am J Physiol 235: 119-125

12. Trimble ER, Siegel EG, Berthoud HR, Renold AE (1980) Intraportal islet transplantation: Functional assessment in conscious unrestrained rats. Endocrinology 106: 791-797

13. Brown J, Clark WR, Molnar IG, Mullen YS (1976) Fetal pancreas transplantation for reversal of streptozotocin-induced diabetes in rats. Diabetes $25: 56-64$

14. Steffens $A B$ (1969) A method for frequent sampling of blood and continuous infusion of fluids in the rat without disturbing the animal. Physiol Behav 4: 833-836

15. Hegre OD, Leonard RJ, Erlandson SL, McEvoy RC, Parsons JA, Elde RP, Lazarow A (1976) Transplantation of islet tissue in the rat. Acta Endocrinol (Suppl) (Copenh) 83:257-281

16. Chisholm GJ, Young JD, Lazarus L (1969) The gastrointestinal stimulus to insulin release. I. secretin. J Clin Invest 48: 1453-1459

17. Pederson RA, Brown JC (1979) Effect of cholecystokinin secretin and gastric inhibitory polypeptide on insulin release from the isolated perfused rat pancreas. Can J Physiol Pharmacol 57: 1233-1237

Received: 8 June 1981

and in final form: 4 December 1981

Dr. J.H. Strubbe

Department of Zoology

State University of Groningen

P. O. Box 14

NL-9750 AA Haren, The Netherlands 